DOI https://doi.org/10.18551/rjoas.2017-01.16

\title{
THE IMPACT OF WORK MOTIVATION AND COMPETENCE ON EMPLOYEE PERFORMANCE THROUGH SERVICE QUALITY IN ADMINISTRATIVE STAFF OF UNIVERSITAS NEGERI JAKARTA, INDONESIA
}

\author{
Pawirosumarto Suharno*, Dara Despinur \\ University of Mercu Buana, Indonesia \\ *E-mail: suharno70@yahoo.com
}

\begin{abstract}
This study aims to examine the influence of employee motivation and competence on the performance and also to assess the effect of employee motivation and competence towards its performance through service quality variables. The sample used in this study was 120 employees spread across work units at University of Negeri Jakarta. The method used in this research was Structural Equation Model (SEM) with Lisrel analysis tool software. The research proves that 3 hypotheses from 5 hypotheses were accepted, namely, employee competence affected service quality, employee motivation influenced employee performance, and service quality affected employee performance. While on the other hand, the two hypotheses were rejected; employee motivation could not influence service quality and employee competence was not able to affect work performance.
\end{abstract}

\section{KEY WORDS}

Work motivation, employee competence, quality service, employee performance.

A civil servant is a government personnel who is oriented in providing services to the public in accordance with their field of duty. Good employee competence is needed in order to establish a good service. The higher the competence of the employee, the higher the performance of the organization and vice versa. Employee competence is very important due to organizational performance improvement. In a government sector, qualified personnel will improve the quality of the community service, so that, a government seems to always continue improving the quality of its public service and provides a decent life for its people (Abomaleh and Zahari, 2014).

The quality of the employees in public organization like in a governance system is reflected by the competence of its civil servants who have the duty to manage the organization. A competent employee will enhance the quality of the community service and will affect the government to run better. Employee competency gives a significant positive effect on employee performance (Arifin, 2015). What is meant by employee performance in here include human resources which are developed through competencies improvement and has a positive and significant impact towards employee performance. The enhancement of employee competence is carried out by assessing the human resources management, particularly about the labor issues which are arranged in the order of the functions. To be effective and efficient in achieving the organization's goals, the demand to acquire, develop, and retain the qualified resources is increasingly urgent in accordance with the dynamics of the environment and the ever-changing technology. The human resources strategy also involves the competence problem like in technical ability, conceptual issue, and public relations. The impact of employee competency in employee performance can be seen from the level of competence which has practical implications for human resources planning. It also can be seen from the illustration that knowledge and skills competency tend to be relatively more real and exist on the surface, this is one of the characteristics of the employee.

Employee competence could affect service quality and employee performance. In this case, service quality is still a today's issue for Universitas Negeri Jakarta. Furthermore, the preliminary survey shows that the service satisfaction index in 2015 is still relatively low in which it can be seen in Figure 1. 


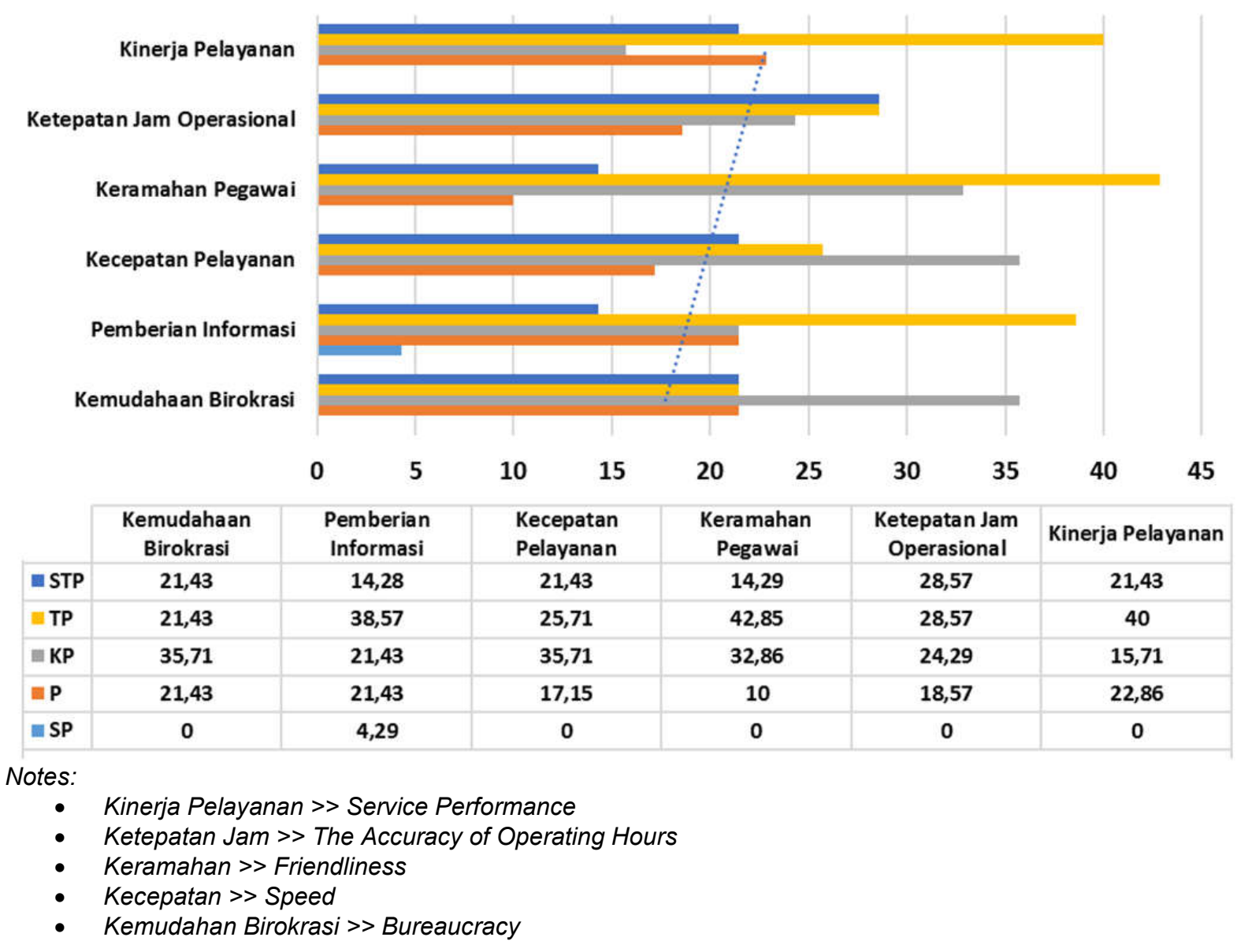

Figure 1 - Employee Service Satisfaction Index

Figure 1 shows that the customer satisfaction index of service quality in the administrative staff of Universitas Negeri Jakarta is still relatively low. In details, from 6 indicators (bureaucracy, speed, friendliness, the accuracy of operating hours, information provision, and service performance), only 1 indicator which is the information provision that received a very satisfied rating where it only rose by $4,29 \%$. The data shows that the average service value provided is at the level of discontent. The level of customer dissatisfaction is able to influence the employee performance so that it becomes a problem by the organization in the future.

Service quality gives an effect to measure the employee performance. The lower the quality of its service, the lower the employee performance measured. The evaluation of employee performance is measured by the output of the employee both in quantity-quality and community satisfaction perception. In accordance with that, service quality and employee performance can be motivated to the maximum in order to achieve better results. Another thing is that service quality and employee performance can be affected by work motivation. The more motivated employees to work, the better the service quality delivered and the better the employee performance measured. The facts show that a good employee of an organization will perform its duties and responsibilities well (Azar and Shafighi, 2013). Meanwhile, according to lqbal et al., (2012) employees' motivation and competence will collectively participate in the employee performance with a variety of difficult assignments given to them. Psychologically, motivation is one of the most important terms for most managers who want maximum output and productivity (Zameer et al., 2014).

Employee competence and motivation in a governance system become a very important aspect, with a good competence, the service quality will be improved and the employee performance will be increased as well. Employee competence, one of which, is strongly influenced by educational background. This statement is in line with what is felt by 
the current government as stated by Mr. Yudhi Crisnandi, the Minister of State Apparatus Empowerment and Bureaucratic Reform on Harian Kompas, February 16th, 2016 that the government has a target to increase the number of highly educated state officials in order to improve the quality and professionalism of the service apparatus. The data presented in Table 1 demonstrate many variables which are targeted to be achieved by the government.

Table 1 - The Targeted Education Level of Civil Servant

\begin{tabular}{|c|c|c|c|}
\hline No & Education & Total Current (\%) & Upcoming Target (\%) \\
\hline 1 & Undergraduate Degree (S1) & 42 & 50 \\
\hline 2 & Postgraduate Degree (S2) & 5 & 10 \\
\hline 3 & Doctoral Degree (S3) & 1,1 & - \\
\hline
\end{tabular}

Source: Harian Kompas, February 2016.

Employee competency is not the only factor which affects the service quality and performance; there is another factor which is the work motivation. Motivation will lead to the fact that employees will perform their duties and responsibilities seriously (Azar and Shafighi, 2013). This means that employees who have a high enough intelligence could fail due to a lack of motivation. Motivation is the concept of events and phenomena associated with the people in a work context. In this research, the work motivation observed is the motivation to come to work through the employee attendance index. The following Figure 2 shows the employee attendance index in 2016 which is still not maximal.

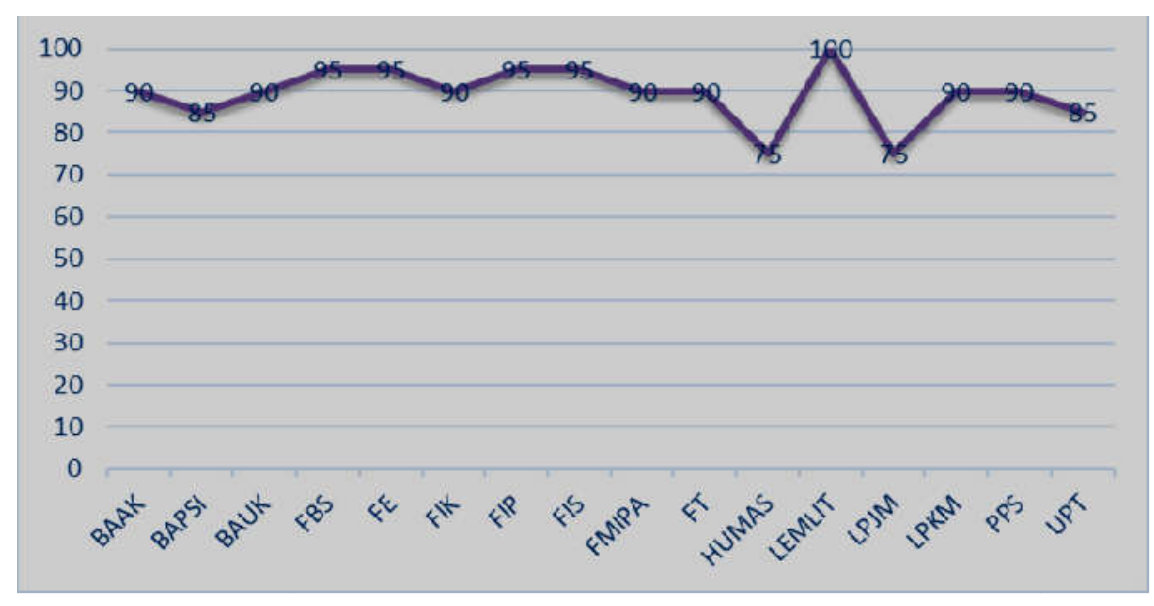

Figure 2 - Employee Attendance Index

The above data show that there is still an employee attendance index by $75 \%$ while the minimum attendance index set by the organization is by $90 \%$. The presence of an employee is one of the work motivations in which it will directly affect the employee performance. Employee performance is very important for the company in order to survive and be successful. Also, employee behavior towards customers has a direct impact on the customer's impression of the quality of services provided (Abomaleh and Zahari, 2014).

\section{THEORETICAL REVIEW}

Motivation is the most important thing for any public or private sector organizations. This is supported by the statement that motivation plays an important role in the success of any organization either in the public or private sector (Chintalloo and Mahadeo, 2013). According to Chaudhary and Sharma (2012), basically, motivation comes from the word "motive». "Motive» means the needs, wants, and desires of the people. So, employee motivation means the process by which the organization inspires employee in the form of rewards, bonuses, and others to achieve organizational goals. The theory of motivation developed by Abraham H. Maslow in Hariandja (2007) was essentially revolves around the 
notion that humans have five levels or hierarchy of needs, namely: (1) physiological needs, (2) safety needs, (3) social needs, (4) esteem needs, and (5) self-actualization.

Competence includes various technical and non-technical factors, personality and behavior, soft skills and hard skills. Competence is widely used as the aspects to recruiting employees for many organizations. According to Spencer in Sutoto (2004), he defined competence as the underlying characteristic of an individual that is causally related to criterion referenced effective and or superior performance in a job situation.

Service quality can be determined by comparing the perceptions of consumers for the services that they obviously received the services that they expected to get through the attributes of an enterprise service. If the received service or perceived service is what they have expected, then the perceived service quality is good and satisfactory. Moreover, if the received service is exceeding the consumers' expectation, then the perceived service is superb. While conversely, if the received service is lower than expected, then the perceived service is classified as a poor quality of service. Kotler (2002) explained that the definition of service is any action or activity that can be offered by one party to another, which is essentially intangible and does not result in any ownership; its production may be linked or not linked to a physical product. A service is the producer behavior carried out to meet consumer needs and desires in order to achieve customer satisfaction. Kotler also said that behavior could be occurred during, before or after the transaction

Performance comes from the word "job performance" or "actual performance", means that this is the actual performance or achievement attained by a person. The performance also can be described as the result of the quality and quantity of work accomplished by an employee in performing its functions in accordance with the responsibilities given to him. Performance is the result or output of a process (Nurlaila, 2010). Performance is also illustrated as an overview of the level of achievement in a program, policy or activity in order to realize the goals, objectives, vision and mission of the organization through the strategic planning of an organization (Moeheriono, 2012).

Several previous types of research have linked the influence of motivation and competence to employee performance and service quality levels in an organization. The research was either conducted in Indonesia or outside Indonesia in which the author here tries to collect some previous research that was relevant and related to this research. By that, this can be seen in Table 2 as follows:

Table 2 - Previous Research

\begin{tabular}{|c|c|c|c|c|}
\hline No & $\begin{array}{c}\text { Author } \\
\text { Name, Year }\end{array}$ & Research Title & Research Variable & Conclusion \\
\hline 1 & $\begin{array}{c}\text { Muhammad } \\
\text { Arifin, } \\
2015\end{array}$ & $\begin{array}{c}\text { The Influence of Competence, } \\
\text { Motivation, and Organisational } \\
\text { Culture to High School } \\
\text { Teacher Job Satisfaction and } \\
\text { Performance }\end{array}$ & $\begin{array}{c}\text { Competence, } \\
\text { Motivation, } \\
\text { organizational } \\
\text { culture, satisfaction, } \\
\text { and performance }\end{array}$ & $\begin{array}{c}\text { Competence and job satisfaction } \\
\text { have a positive and significant } \\
\text { impact on teacher performance } \\
\text { and organizational culture but not } \\
\text { on job satisfaction. }\end{array}$ \\
\hline 2 & $\begin{array}{c}\text { Hashim } \\
2014\end{array}$ & $\begin{array}{c}\text { The Impact of the Motivation } \\
\text { on the Employee's } \\
\text { Performance in Beverage } \\
\text { Industry of Pakistan }\end{array}$ & $\begin{array}{c}\text { Motivation and } \\
\text { Performance }\end{array}$ & $\begin{array}{c}\text { Motivation plays an important } \\
\text { role on the performance of } \\
\text { employees in the beverage } \\
\text { industry of Pakistan }\end{array}$ \\
\hline 3 & $\begin{array}{c}\text { Ukaejiofo } \\
\text { Rex Uzonna, } \\
2013\end{array}$ & $\begin{array}{c}\text { Impact of motivation on } \\
\text { employees" performance: A } \\
\text { case study of CreditWest Bank } \\
\text { Cyprus }\end{array}$ & $\begin{array}{c}\text { Motivation and } \\
\text { Employee } \\
\text { Performance }\end{array}$ & $\begin{array}{c}\text { Employee motivation related to } \\
\text { employee performance }\end{array}$ \\
\hline 4 & $\begin{array}{c}\text { Muhammad } \\
\text { Bilal Ahmad, } \\
2012\end{array}$ & $\begin{array}{c}\text { Impact of employee motivation } \\
\text { on customer satisfaction: study } \\
\text { Of airline industry in Pakistan }\end{array}$ & $\begin{array}{c}\text { Employee motivation } \\
\text { and Customer } \\
\text { Satisfaction }\end{array}$ & $\begin{array}{c}\text { Employee motivation gives a } \\
\text { positive and significant impact on } \\
\text { customer satisfaction }\end{array}$ \\
\hline
\end{tabular}

Then, the conceptual framework of the research was built based on the previous theory and research which were relevant to this research. The conceptual framework of the research is presented in this following Figure 3: 


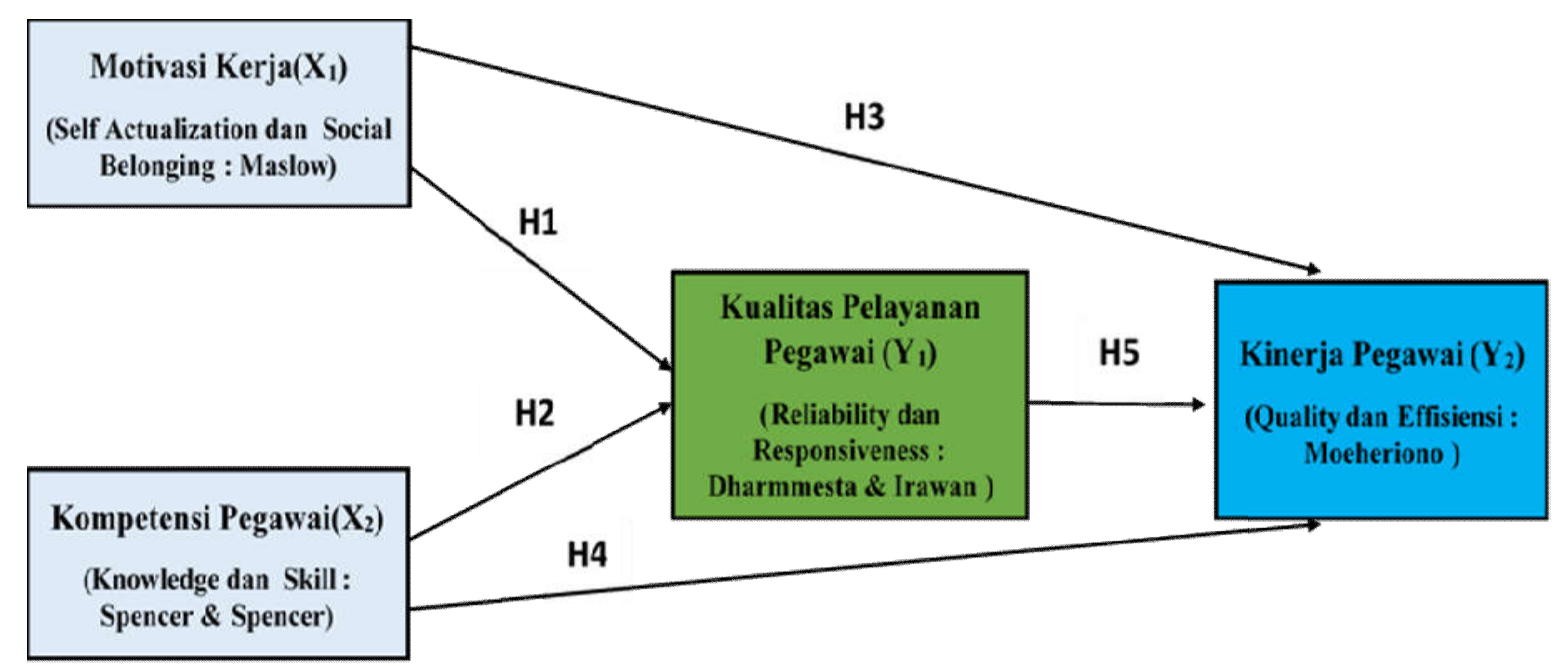

Notes:

- Motivasi $>>$ Work Motivation

- Kompetensi >> Employee Competence

- Kualitas >> Service Quality

- Kinerja >> Employee Performance

Figure 3 - Research Framework

Based on the theory, previous research, and research framework, the hypothesis proposed in this study are: work motivation is affected service quality positively; employee competence gives positive effect on service quality; work motivation delivers a positive influence on employee performance; employee competence positively affected employee performance; service quality has a positive impact on employee performance.

\section{RESEARCH METHODS}

The approach of this research was conducted by using a description method in which will examine the status of human groups, an object, a set of conditions, a system of thought, or a class of events in present. Descriptive research is intended to study the problems in a society as well as the applicable procedure in a community and specific situations including relationships, activities, attitudes, views, on-going processes, and phenomenon effects. This research was also an explanatory research, investigators tried to determine the relationship between variables based on the data obtained from the determined sample through the observation unit survey. The research variables were measured by using the development instruments which were used in previous studies, making it possible to improve the measurement validity and reliability. The measurement of each variable was carried out by using Likert scale of 1 to 5 with variables operationalization on Table 3.

The population is the generalization region which consists of objects or subjects that have certain qualities and characteristics defined by the researchers to learn and then to draw a conclusion (Sugiyono, 2011). Moreover, according to Sumarsono (2005), a population is a group of subjects or objects that have different traits or characteristics from other subjects or objects group. The population chosen in this study was the administrative staff of Universitas Negeri Jakarta and spread over in 11 units with the total of 456 employees. Next, Sugiyono (2011) stated that a quota sampling technique is a technique which is used to determine the sample of the population that has certain characteristics to the desired total quota. In this study, the number of sampling had been set at 120 sampling in which this was taken proportionally from each unit. The data distribution of the population and the sample is presented in Table 4.

The data analysis was performed by using Structural Equation Model (SEM). The main reason of the use of SEM in this research was the ability to analyze the relationship pattern 
between latent constructs and its indicators, latent constructs with one another, and to analyze the measurement error. SEM allows the researcher to do an analysis in multiple dependent and independent variables directly (Hair et.al., 2006). In this study, the software used to support the study was Lisrel 8.8.

Table 3 - Operationalization of Research Variables

\begin{tabular}{|c|c|c|c|c|}
\hline Variable & Dimension & & Indicator & $\begin{array}{l}\text { Measure } \\
\text { Scale }\end{array}$ \\
\hline \multirow{6}{*}{ Work Motivation (X1) } & \multirow{3}{*}{$\begin{array}{l}\text { Self-Actualization } \\
\text { (Maslow Theory) }\end{array}$} & 1 & The desire to go forward & Ordinal \\
\hline & & 2 & Self-achievement potential & Ordinal \\
\hline & & 3 & Creative nature & Ordinal \\
\hline & \multirow{3}{*}{$\begin{array}{l}\text { Social needs } \\
\text { (Maslow Theory) }\end{array}$} & 4 & Relationships with co-workers & Ordinal \\
\hline & & 5 & Relationship with supervisor & Ordinal \\
\hline & & 6 & Teamwork & Ordinal \\
\hline \multirow{6}{*}{$\begin{array}{c}\text { Employee } \\
\text { Competence (X2) }\end{array}$} & \multirow{3}{*}{$\begin{array}{l}\text { Knowledge } \\
\text { (Spencer and } \\
\text { Spencer) }\end{array}$} & 7 & $\begin{array}{l}\text { An understanding about duties and } \\
\text { responsibilities }\end{array}$ & Ordinal \\
\hline & & 8 & $\begin{array}{c}\text { The knowledge of procedures and } \\
\text { technical services }\end{array}$ & Ordinal \\
\hline & & 9 & The knowledge about regulations & Ordinal \\
\hline & \multirow{3}{*}{$\begin{array}{c}\text { Skills } \\
\text { (Spencer and } \\
\text { Spencer) }\end{array}$} & 10 & Administrative skills & Ordinal \\
\hline & & 11 & Technical skills & Ordinal \\
\hline & & 12 & Social skills & Ordinal \\
\hline \multirow{6}{*}{ Service Quality (Y1) } & \multirow{3}{*}{$\begin{array}{c}\text { Reliability } \\
\text { (Dharmmesta and } \\
\text { Irawan) }\end{array}$} & 13 & $\begin{array}{l}\text { Employee's reliability in providing } \\
\text { information }\end{array}$ & Ordinal \\
\hline & & 14 & $\begin{array}{l}\text { Employee's reliability in technical } \\
\text { services }\end{array}$ & Ordinal \\
\hline & & 15 & $\begin{array}{l}\text { Employee's reliability in answering } \\
\text { customer questions }\end{array}$ & Ordinal \\
\hline & \multirow{3}{*}{$\begin{array}{c}\text { Responsiveness } \\
\text { (Dharmmesta and } \\
\text { Irawan) }\end{array}$} & 16 & Employee's responses to complaints & Ordinal \\
\hline & & 17 & Employee's responses to suggestions & Ordinal \\
\hline & & 18 & Employee's responses to the queue & Ordinal \\
\hline \multirow{6}{*}{$\begin{array}{c}\text { Employee } \\
\text { Performance (Y2) }\end{array}$} & \multirow{3}{*}{$\begin{array}{c}\text { Quality } \\
\text { (Moeheriono) }\end{array}$} & 19 & The quality of the work & Ordinal \\
\hline & & 20 & The frequency of making mistakes & Ordinal \\
\hline & & 21 & The ability to work under pressure & Ordinal \\
\hline & \multirow{3}{*}{$\begin{array}{l}\text { Efficiency } \\
\text { (Moeheriono) }\end{array}$} & 22 & The efficiency of labor costs & Ordinal \\
\hline & & 23 & The dexterity of work & Ordinal \\
\hline & & 24 & The speed of works & Ordinal \\
\hline
\end{tabular}

Table 4 - The Distribution of Research Population and Sample

\begin{tabular}{|l|c|c|c|}
\hline \multicolumn{1}{|c|}{ Observation Unit } & Population & Sample & \% Total Population \\
\hline Administration Bureau of Academic Affairs and Cooperation & 20 & 5 & 1,10 \\
\hline BAPSI & 14 & 4 & 0,87 \\
\hline Administration Bureau of General Affairs and Human Resources & 114 & 30 & 6,58 \\
\hline Faculty of Language and Art & 25 & 6 & 1,31 \\
\hline Faculty of Economics & 15 & 4 & 0,87 \\
\hline Faculty of Sport Sciences & 19 & 5 & 1,10 \\
\hline Faculty of Political Sciences & 32 & 8 & 1,75 \\
\hline Faculty of Social Sciences & 17 & 5 & 1,10 \\
\hline Faculty of Mathematics and Natural Sciences & 29 & 8 & 1,75 \\
\hline Faculty of Engineering & 38 & 10 & 2,20 \\
\hline Technical Implementation Unit and others & 133 & 35 & 7,68 \\
\hline Total Population & 456 & 120 & 26,31 \\
\hline
\end{tabular}

Source: Universitas Negeri Jakarta, processed by authors in 2016. 


\section{RESULTS AND DISCUSSION}

The test of the dimensionality of a construct was performed by using a confirmatory factor analysis. In general, before making the structural model analysis, the first thing to do was establishing the measurement model in order to test the validity and reliability of the indicators by performing Confirmatory Factor Analysis (Latan, 2013). After the validity and reliability test was implemented, the suitability test of the model must be conducted. The suitability test results is presented in this following table:

Table 5 - Goodness-of-fit Test Results

\begin{tabular}{|c|c|c|c|c|}
\hline Fit Measure & Good Fit & Acceptable Fit & Score Research & Result \\
\hline $\mathrm{X}^{2}$ & $0 \leq \mathrm{x}^{2} \leq 2 \mathrm{df}$ & $2 \mathrm{df} \leq \mathrm{x}^{2} \leq 3 \mathrm{df}$ & 258,99 & Good Fit \\
\hline P value & $.05<\mathrm{p} \leq 1.00$ & $.01 \leq \mathrm{x}^{2} \leq .05$ & 0,272 & Not Fit \\
\hline RMSEA & $0 \leq \mathrm{RMSEA} \leq .05$ & $.05 \leq \mathrm{RMSEA} \leq .08$ & 0,021 & Good Fit \\
\hline $\mathrm{NFI}$ & $.95 \leq \mathrm{NFI} \leq .1 .00$ & $.90 \leq \mathrm{NFI} \leq .95$ & 0,94 & Good Fit \\
\hline $\mathrm{NNFI}$ & $.97 \leq \mathrm{NNFI} \leq .1 .00$ & $.95 \leq \mathrm{NNFI} \leq .97$ & 0,99 & Good Fit \\
\hline $\mathrm{CFI}$ & $.97 \leq \mathrm{CFI} \leq .1 .00$ & $.95 \leq \mathrm{CFI} \leq .97$ & 0,99 & Acceptable Fit \\
\hline GFI & $-95 \leq \mathrm{GFI} \leq .1 .00$ & $-90 \leq \mathrm{GFI} \leq . .95$ & 0,92 & Acceptable Fit \\
\hline AGFI & $-90 \leq \mathrm{AGFI} \leq .1 .00$ & $-85 \leq \mathrm{AGFI} \leq .90$ & 0,86 & \\
\hline
\end{tabular}

Source: Data analysis by using Lisrel (2016).

The data of goodness of fit statistics above shows that the NFI, NNFI, CFI, GFI are greater than 0,90 while RMSEA is more or less than 0,08 . This means that the overall model is in good level (good fit). Meanwhile, AGFI is at $0,80 \leq \mathrm{GFI} \leq 0,90$, this shows that the indicators are in an acceptable fit. In the other hand, the p-value which is by 0,0272 shortly shows that it is less matched. From the combination of those various matched measurements, generally, it can be concluded that the overall measurement is a good fit. Table 5.10 above shows that all the testing criteria show such good results. The test is intended to generate a good confirmation on the dimensions and causality between factors so that we can conclude that the overall model is acceptable. From the results above, we can have estimated the model estimation as follows:

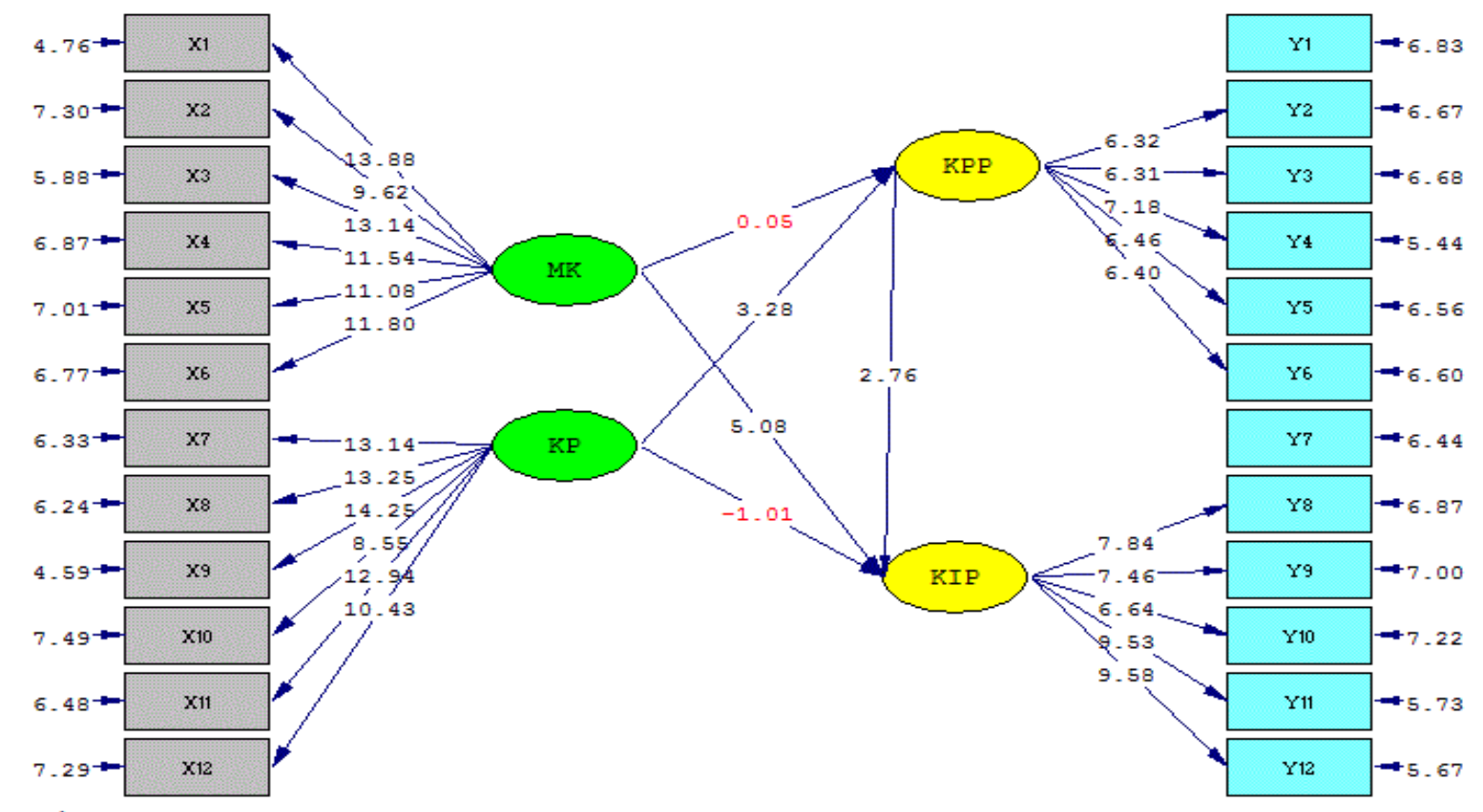

Chi-Square=258.99, df $=246$, P-value $=0.27238$, RMSEA $=0.021$

Figure 4 - T-value Model Diagram 
In Figure 4, the coefficient value of the constructs is obtained and the loading factor, as well as the t-value, has been qualified. In the goodness-of-fit model above, most of the indicators that are likely to fit the model have reached the value of a good fit. The test shows that the value of the construct has met the required value in which the significance test can be said to be significant if the t-count is larger than t-table. The t-value used in this study was 1,96 with the significance level of $95 \%$. In addition, to see the magnitude of the effect between the latent variables, not only from the t-value model but it can be seen from the estimated resulting model. In this study, the result of the estimation model is illustrated in Figure 5:

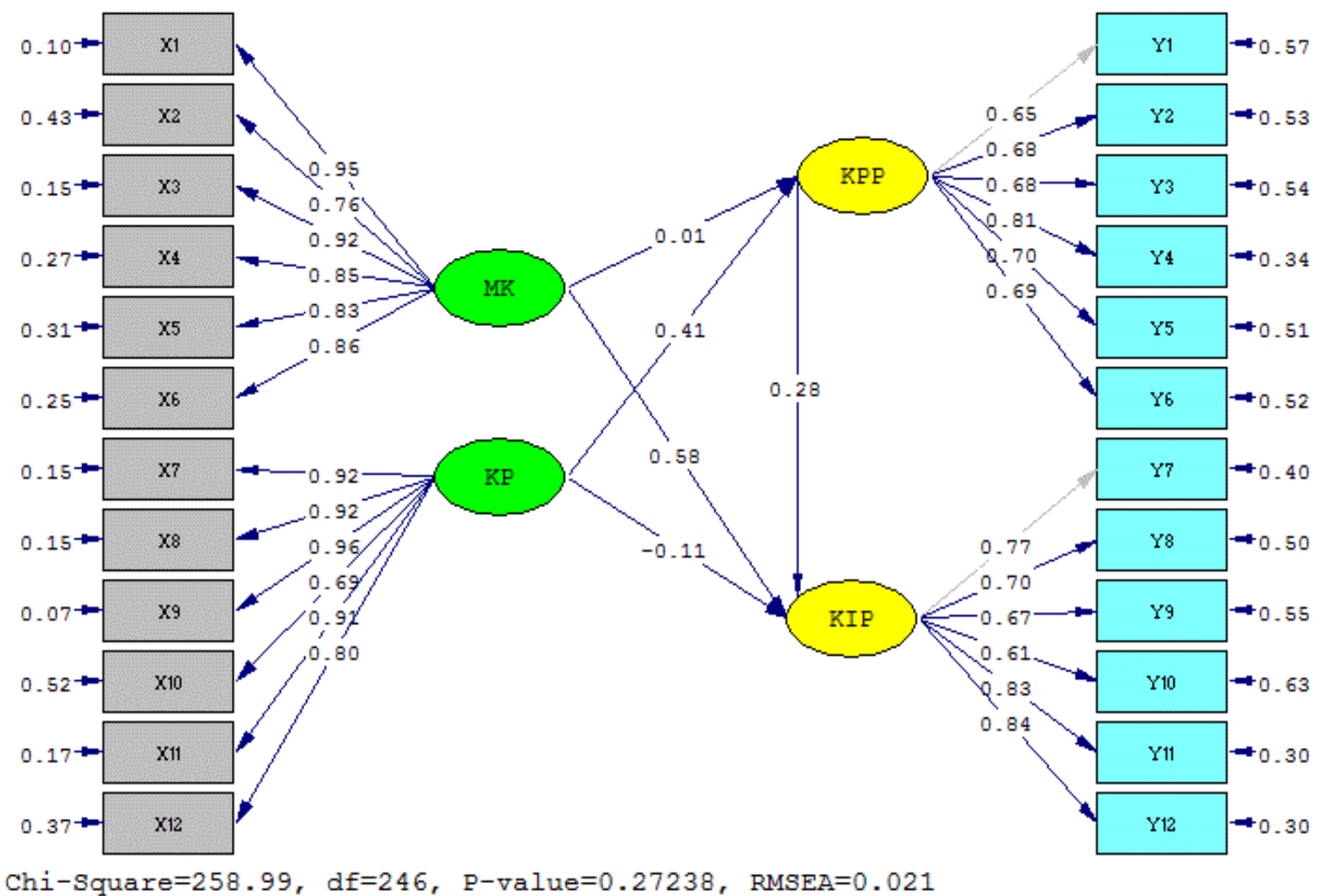

Figure 5 - Standardized Solution Model Diagram

The model above shows that the value met all the required standards. After seeing the combination of various matched sizes, generally, it can be concluded that the overall suitability of the model is a good fit so that it deserves to be analyzed further. After that, the hypotheses test is implemented and the results are presented in this following table:

Table 6 - Hypotheses Test Results

\begin{tabular}{|c|l|l|l|l|}
\hline No & \multicolumn{1}{|c|}{ Path } & \multicolumn{1}{|c|}{ Estimation } & \multicolumn{1}{c|}{ Conclusion } \\
\hline 1 & $\mathrm{MK} \rightarrow \mathrm{KPP}$ & 0,01 & 0,05 & Not significant \\
\hline 2 & $\mathrm{KP} \rightarrow \mathrm{KPP}$ & 0,41 & 3,28 & Significant \\
\hline 3 & $\mathrm{MK} \rightarrow \mathrm{KIP}$ & 0.58 & 5,08 & Significant \\
\hline 4 & $\mathrm{KP} \rightarrow \mathrm{KIP}$ & $-0,11$ & $-1,01$ & Not significant \\
\hline 5 & $\mathrm{KPP} \rightarrow \mathrm{KIP}$ & 0,28 & 2,76 & Significant \\
\hline
\end{tabular}

Based on the data which was processed by using SEM method as described above, the discussion of the results is presented in a comprehensive manner as follows:

Work Motivation is Influenced Service Quality. The result showed that the t-value of 0,05 is smaller than t-value in the table which is 1,96 , so the hypothesis 0 is accepted and hypothesis 1 is rejected. The results of statistical analysis showed that motivation did not affect the quality of services in Universitas Negeri Jakarta. It is proven by the influence of 
motivation to service quality which only impacted by $1 \%$ in which this indicated that the size of the loading factor is worth at 0,01 .

The study concluded that in order to improve the service quality, the management or rector in Universitas Negeri Jakarta should consider the above indicators. Leaders need to encourage the employees to improve their potential in terms of moving forward, creativity, and have a good teamwork through the approach of motivational training, for example, provides a clear reward and punishment. This needs to be done in order to improve the reliability of employees in technical service, the reliability in answering questions and in response to the complaints. How? This effort could be carried out by developing an exciting work environment that aims to motivate employees in the work so that their contribution in solving and achieving organizational goals could be achieved (Ahmad et.al, 2012). Besides that, the desire to move forward, creativity and teamwork can be enhanced through the provision of rewards and punishment, this is in line with the research of Simon and De Varo (2006), they said that companies can motivate their employees by offering a good salary, organizational culture and promotion opportunities.

Employee Competency Affecting Service Quality. The result showed that t-value of 3,28 is larger than the value in the table which is 1,96 . This means that the hypothesis 0 is rejected and hypothesis 2 is accepted. The results of statistical analysis showed the influence of employee competence and service quality by the loading factor value of 0,41 in which this means that there is an influence in between employee competence to service quality by $41 \%$. Employee competence in the form of rules, technical procedures, duties and responsibilities understanding will significantly affect the reliability of the employees in providing technical service, answering customer inquiries, and handling complaints. This is in line with the previous studies of Nurmasitha et.al. (2016) which stated that employee competence and working environment have a significant effect on the service quality. To maintain and improve the quality of the service, employee competence must be improved by the management, for example, through the provision of regular socialization and training which are scalable and sustainable.

Work Motivation has an Impact towards Employee Performance. The analysis showed that $\mathrm{t}$-value of 5,08 is larger than $\mathrm{t}$-value in the table which is 1,96 . So, associated to that, hypothesis 0 is rejected and hypothesis 3 is accepted. The statistical analysis showed that motivation could influence employee performance. The magnitude of the effect is shown by the value of the loading factor by 0,58 , this shows that the influence of work motivation on employee performance at Universitas Negeri Jakarta is $58 \%$. This study confirms the previous research of Azar and Shafighi (2013) which indicated that motivation will lead to the fact that employee will seriously carry out its duties and responsibilities in the organization. A good salary is a valuable motivational tool and plays an important role to improve employee performance also to increase organizational productivity. The study also in line with the research conducted by lqbal et. al. (2012), he stated that, collectively, employees' motivation and ability will participate in its performance and the difficult tasks given to them. Furthermore, this study also provides support for research of Zameer et. al (2014), motivation plays an important role on the performance of employees. This motivation can be improved, for example through awards, capacity building training, work comfort improvement and employee's career and welfare consideration.

Employee Competency Affects Employee Performance. The data analysis shows that the t-value of $-1,01$ is smaller than $t$-value in the table by 1,96 , This means that hypothesis 0 is accepted and hypothesis 4 is rejected. From the results of statistical analysis above, it can be concluded that the competence of the employees does not affect the performance of employees in Universitas Negeri Jakarta. In details, the amount of the influence is only $11 \%$ where it was indicated from the loading factor value by 0,11 .

This study shows that the competence indicators does not significantly affect the working dexterity, speed, and quality. This research is not in line with the previous studies like the research of Arifin (2015) which referred that the employee competence is positively and significantly affecting the employee performance. In the other hand, this result is different from Lawler et.al. (2012) research, he thought that in the case of management 
performance, the use of competency assessment seems to be quite extensive. Competence is positively related to individual performance and managerial performance, it can be enhanced with a competence system mentoring. This indicated that most of the employees in Universitas Negeri Jakarta feel that their performance is not affected by their capacity but influenced by their motivation as described above, or may be influenced by other factors which are not examined in this study such a leadership commitment, culture and working environment, working facilities or comfort environment

Service Quality Influencing Employee Performance. The result of the data analysis described above shows that the t-value of 2,76 is greater than the t-value in the table $(1,96)$ in which this means that hypothesis 0 is rejected and hypothesis 5 is rejected. It indicates that there is a significant impact on employee performance by $28 \%$. The amount of how big the effect is shown on the loading factor value by 0,28 .

This study provides an empirical evidence to the previous studies and supports previous research which examines employee reliability in providing technical service, in answering customer questions, and in handling complaints. This may increase the size of the work dexterity, speed, and quality. The quality of service provided to employees can affect the size of employee performance. This is in line with the research of Purwatiningsih (2015), there is a close relationship between service quality to employee performance. The study also confirms previous research conducted by Abomaleh and Zahari (2014), it is said that the behavior of employees to customers is reflected in the quality of services that have such immediate impact on customer satisfaction.

\section{CONCLUSION}

This study demonstrates the factors that affect service quality and the impact on employee performance. From 5 hypotheses proposed at the beginning of the study, 3 hypotheses were accepted and 2 hypotheses were rejected, with the following conclusions:

1. Work motivation does not influence the service quality. This shows that most of the administrative staff in Universitas Negeri Jakarta felt that service quality they provide does not depend on the motivation they have, but depends on other factors, such as leadership style, work culture, management commitment, or any other factors.

2. Employee competence affected service quality. This study confirms and supports several previous studies that employee competence has a significant and positive effect on service quality. The better the competency of the employees, the better the quality of the services provided. According to the administration staff in Universitas Negeri Jakarta, employee competence with the indicators of understanding the regulations, technical procedure, duties, and responsibilities will significantly affect the reliability of the employees to provide technical service, to answer customer inquiries and to response complaints. A good competence employee will provide a good service. A qualified service can be delivered to the maximum if the employee has a good competence in their field.

3. Work motivation able to influenced employee performance. This study shows that the majority of the employees in Universitas Negeri Jakarta agreed that their performance is influenced by motivation. The more motivated employees to work, the better the performance. Thus, the motivation needs to be maintained and enhanced, for example, through awards, training capacity building, work comfort improvement as well as employee's career and welfare consideration.

4. Employee competence has no impact on employee performance. This indicates that most of the employees in Universitas Negeri Jakarta found that their performance is not affected by their capacity, but is influenced by their motivation to work. Although employees have a good competence, but if the employee does not have the motivation to work, the performance will still be low. Most employees also think that their performance is influenced by other factors such as management commitment, culture and working environment, working facilities or comfort environment. 
5. Service quality affects employee performance. The study also shows that most of the employees in Universitas Negeri Jakarta confirmed that employee performance is influenced by the quality of service they provide. The better the quality of the service, then the better their performance. This means that an increase in service quality can improve the performance of the staff in Universitas Negeri Jakarta.

Based on the results and discussion above, the author suggests two things as follows:

This study provides recommendation and advice to Universitas Negeri Jakarta that some of the indicators which are related to service quality and employee performance management should be a serious concern to be considered, namely:

- Employee motivation has a significant impact on employee performance. In order to improve employee motivation, it can be established by using the approach of (1) opportunity to move forward, (2) encourage the growth of creativity, and (3) improving teamwork system. A desire of the employees to keep on moving forward should be encouraged through incentives, rewards (promotions), training and higher education. While on the other hand, creativity can be enhanced through training and some internal competitions to explore creative ideas. Lastly, teamwork can be improved through outbound activities, family gathering, and other activities that can improve cooperation, both among employees and leaders.

- Employee competence has a significant effect on service quality. To develop service quality, management should improve the employee competence by (1) Increasing knowledge about the rules, (2) increasing the understanding of procedures and technical services, and (3) giving an understanding about the duties and responsibilities. The enhancement of employee competence through those indicators should be measured and evaluated regularly. Management should have a short, medium, and long plan in accordance with employee competence through a measurable and continuous training and socialization activities.

- Service quality affected employee performance. The increasing service quality could be developed through (1) employee reliability in providing technical service, (2) employee reliability in answering customer questions, and (3) employee reliability in handling complaints. By that, the size of an employee's performance will be better. In terms of service reliability and speed, handling a complaint is something that must be really concerned of. Management should be able to monitor every moment of the service and able to provide adequate facilities in the community.

Further research needs to consider the use of a broader sampling. This is necessary to be carried out so that the results and conclusions of data analysis can reflect and portray the real condition. Besides, further research is very important to be conducted in order to examine other factors such as work culture, management commitment, and also environmental factors, because it relates to what the author have found during this research.

\section{REFERENCES}

1. Abomaleh a Awad, Zahari Ibrahim. 2014. The impact of management commitment to service quality and customer satisfaction: A Review of Saudi Arabia public service sector. Journal of Modern Marketing Research Vol.3 No.1, June 2014. pp 15-24.

2. Ahmad M.,Wasay Ejaz., dan Malik S. 2012. Impact of employee motivation on customer satisfaction: study of airline industry in pakistan. Interdiciplinary Journal of Contemporary Research in Business. Vol. 4, No.6. 531-539

3. Arifin, H. Muhammad. 2015. The Influence of Competence, Motivation, and Organisational Culture to High School Teacher Job Satisfaction and Performance. International Education Studies ISSN 1913-9020. Vol. 8, No. 1, January 2015. 38-45

4. Azar, M., and Shafighi, A.A. 2013. The effect of work motivation on employees' job performance. International journal of academic research in business and social science. $432-445$ 
5. Chintalloo, S and Mahadeo, J. 2013. Effect of Motivation on Employees' Work Performance at Ireland Blyth Limited: Proceedings of 8th Annual London Business Research Conference Imperial College, London, UK, 8 ISBN: 978-1-922069-28-3. 1 - 16

6. Chaudhary, N., Sharma, B. 2012. Impact of Employee Motivation on Performance (Productivity) In Private Organization. International Journal of Business Trends and Technology- volume 2 Issue4. 2012. 29-35

7. Hair, et al. 2006. Multivariate Data Analysis. Sixth Edition. New Jersey: Pearson Education

8. Hariandja, Efendi. 2007. Manajemen Sumber Daya Manusia. Pengadaan, pengembangan, Pengkompensasian dan Penngkatan Produktifitas Pegawai. Garsindo.

9. Iqbal, J. Yusaf, A. Munawar, R. Naheed, S. 2012. Employee Motivation in Modern Organization: Interdisciplinary Journal of Contemporary Research in Business, Vol. 4, No. 3. $692-708$

10. Kotler, Philip. 2002. Manajemen Pemasaran di Indonesia : Analisis, Perencanaan, Implementasi dan Pengendalian. Salemba Empat. Jakarta

11. Latan, Hengky. 2013. Structural Equation Modeling. Konsep dan Aplikasi Menggunakan Program LISREL 8,80. Alfabeta.

12. Lawler E. et al 2012. Centre of effective Organization. $9-17$

13. Moeheriono. 2012. Pengukuran Kinerja Berbasis Kompetensi, edisi revisi, cetakan pertama, Penerbit : Raja Grafindo Persada, Jakarta

14. Nurmasitha, Faiza. 2016. Pengaruh Kompetensi Pegawai Dan Lingkungan Kerja Terhadap Kualitas Pelayanan (Studi pada Dinas Kependudukan dan Pencatatan Sipil Kabupaten Sidoarjo). Jurnal Administrasi Publik (JAP), Vol. 1, No. 6, Hal. 1220-1228

15. Nurlaila. 2010. Manajemen Sumber Daya Manusia I. Ternate: Penerbit LepKhair

16. Purwatiningsih. 2015. Analisis Pengaruh Dimensi Kualitas Pelayanan Terhadap Kinerja Karyawan Amik Cipta Darma Surakarta.Among Makarti. Vol.8 No.15. 78 - 84

17. Simon H. Daniel and Varo,Jed De. 2006. Do the Best Companies to Work for Provide Better Customer Satisfaction. Publikasi Cornell University. DigitalCommons. 1-30

18. Sugiyono, 2011. Metode Penelitian Kuantitatif, Kualitatif dan RandD. Alfabeta.

19. Sumarsono, 2005. Pertanian Organik. Cetakan Pertama. Badan Penerbit Universitas Diponegoro, Semarang.

20. Sutoto, D. 2004. Dimensi Tingkat Kompetensi. Artikel (http://www.petra.ac.id).

21. Zameer, Hashim et al. 2014. The Impact Of Motivation On The Employee's Performance In Beverage Industry Of Pakistan International. Journal Of Acedemic Research In Accounting, Finannce Management Sciences.Vol 4 No.1. $293-298$ 